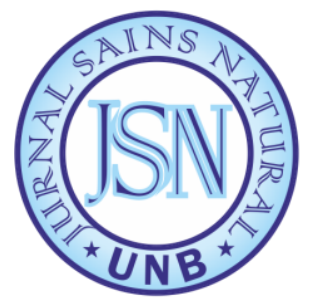

\title{
EFFECTIVENESS OF CAPORITE TO REDUCE CONCENTRATION OF IRON AND MANGAN IN CILIWUNG RIVER WATER AS RAW WATER PDAM
}

\author{
Nadhila Aulia Dwiputri ${ }^{1)}$, Mia Azizah ${ }^{2)^{*}}$, Nurlela $^{1)}$ \\ ${ }^{1)}$ Program Studi Kimia, FMIPA, Universitas Nusa Bangsa Bogor \\ ${ }^{2)}$ Program Studi Biologi, FMIPA, Universitas Nusa Bangsa Bogor \\ Jl. KH. Sholeh Iskandar KM 4, Cimanggu, Tanah Sareal, Bogor 16166, Indonesia
}

\section{ARTICLE INFO}

Article history:

Received 10 Jan 2021,

Accepted 17 Mar 2021

Available online 29 Apr 2021

Keywords:

$$
\begin{aligned}
& \checkmark \text { Caporite, } \\
& \checkmark \text { Iron, } \\
& \checkmark \text { Manganese, } \\
& \checkmark \text { Ciliwung River, } \\
& \checkmark \text { Regulation }
\end{aligned}
$$

*corresponding author: miaazizah23@gmail.com Phone: +62

$\underline{\text { https://doi.org/10.31938/jsn.v }}$ $\underline{11 \mathrm{i} 1.295}$

\begin{abstract}
The water of the Ciliwung river used as raw water for PDAM Depok contains iron and manganese, which levels were quite high and exceeded the quality standard. The purposes of the research are to determine the effectiveness of caporite to reduce levels of iron and manganese to reach levels that meet the standards of Government Regulation Number 82 of 2001. The sample used in this study was the water of the Ciliwung river used as a source of raw water for PDAM Depok with two different water treatment plant (WTP) locations, location 1 in Legong WTP and location 2 in Citayam WTP. Raw water was taken using a submersible water pump located at the bottom of the Ciliwung river. The analytical method used as a reference for determining iron levels was based on the FerroZine Rapid Liquid Method 1970, and for manganese levels was based on 1- (2Pyridylazo) -2-Naphthol PAN Method 1977, both methods using the Spectrophotometric method. The results showed that iron and manganese levels were quite high, exceeding the standards of Government Regulation No.82 of 2001 with a maximum standard of iron content is $0.3 \mathrm{mg} / \mathrm{L}$, and a maximum standard of manganese level is $0.1 \mathrm{mg} / \mathrm{L}$. After adding a certain dose of chlorine to Ciliwung river water in the Legong and Citayam WTPs, it was found that chlorine effectively reduced Fe and Mn levels because it was able to reduce levels up to $80 \%$ and meet the quality standards.
\end{abstract}

\section{ABSTRAK \\ Efektivitas kaporit untuk menurunkan kadar besi dan mangan dalam air sungai ciliwung sebagai air baku PDAM}

\begin{abstract}
Air sungai Ciliwung yang digunakan sebagai air baku PDAM Depok terdapat zat besi dan mangan dengan kadarnya cukup tinggi serta melebihi ambang baku mutu. Tujuan penelitian ini untuk mengetahui efektivitas kaporit dalam menurunkan kadar besi dan mangan sehingga memenuhi standar baku mutu Peraturan Pemerintah Nomor 82 Tahun 2001 untuk kelas 1. Sampel air yang digunakan dalam penelitian ini diambil dari 2 titik lokasi Instalasi Pengolahan Air (IPA) yang berbeda, yaitu dari IPA Legong dan IPA Citayam. Sampel air baku diambil dengan menggunakan pompa air submersible (pompa celup) yang berada di dasar sungai Ciliwung. Penelitian dilakukan dengan eksperimen jar test di laboratorium. Metode analisis untuk menentukan kadar besi mengacu pada FerroZine Rapid Liquid Method tahun 1970 dan mangan berdasarkan 1-(2-Pyridylazo)-2Napthol PAN Method tahun 1977 dengan menggunakan metode Spektrofotometri. Hasil penelitian menunjukan kadar besi dan mangan yang cukup tinggi hingga melebihi standar yang telah ditetapkan dalam PP No.82 Tahun 2001 dengan kadar Fe maksimal 0,3 mg/L dan kadar Mn maksimal 0,1 mg/L. Setelah dilakukan penambahan bahan kimia kaporit ke dalam sampel air sungai Ciliwung dari IPA Legong dan Citayam, dengan dosis $10 \mathrm{mg} / \mathrm{L}$ untuk penurunan $\mathrm{Fe}$ dan $30 \mathrm{mg} / \mathrm{L}$ untuk penurunan $\mathrm{Mn}$ dapat efektif menurunkan konsentrasi Fe dan Mn hingga $80 \%$, dan memenuhi standar baku mutu yang digunakan.
\end{abstract}

Kata Kunci: Kaporit, Besi, Mangan, Sungai Ciliwung, Baku Mutu 


\section{PENDAHULUAN}

Sungai Ciliwung merupakan salah satu sungai di Kota Depok yang mengalir dari Tugu Puncak, Kabupaten Bogor (hulu) sampai Teluk Jakarta, Jakarta Utara (hilir). Air sungai yang bersumber dari mata air, umumnya memiliki kualitas air yang sangat baik. Namun, air tersebut akan tercemar oleh berbagai polutan dalam proses pengalirannya (Sofia et al., 2010). Jenis - jenis bahan pencemar kimia antara lain zat-zat organik bisa berupa minyak, lemak, detergen, karbohidrat, protein maupun zat-zat anorganik dan zat radioaktif. Menurut Simon dan Hidayat (2008) sebagian besar sungai di Indonesia terutama setelah melewati daerah industri, pertanian, dan pemukiman berada dalam kondisi tercemar.

Batu-batuan yang di dalamnya terdapat senyawa pirit dapat menjadi sumber Fe dalam air. Sedangkan pada limbah industri, $\mathrm{Fe}$ dapat bersumber dari pipa-pipa air berbahan logam yang mengalami korosi (Ginting, 2007). Mangan meskipun tidak memiliki sifat toksik, tapi dapat mepengaruhi logam berat yang memiliki sifat toksik di dalam air (Effendi, 2003).

Berdasarkan penelitian pendahuluan yang dilakukan, ditemukan bahwa sungai Ciliwung yang digunakan sebagai air baku PDAM Depok mengandung zat besi $(\mathrm{Fe})$ sebesar $1,417 \mathrm{mg} / \mathrm{L}$ dan Mangan (Mn) sebesar 0,325 mg/L. Hasil tersebut cukup tinggi dan sudah melebihi Nilai Ambang Batas (NAB) kualitas air berdasarkan PP RI No 82 Tahun 2001 kelas 1 tentang Pengelolaan Kualitas Air dan Pengendalian Pencemaran Air. Air tersebut digunakan sebagai air baku dalam pengolahan dan penyediaan air bersih oleh PDAM yang sampai saat ini belum melakukan treatment untuk menurunkan kadar logam tersebut dan apabila air tersebut digunakan dalam pengolahan dengan kandungan Fe dan Mn yang cukup tinggi, akan mempengaruhi proses pengolahannya.

Ada berbagai metode yang digunakan untuk penurunan konsentrasi $\mathrm{Fe}$ dan $\mathrm{Mn}$ di dalam air yaitu dengan cara fisik, kimiawi, biologis, ataupun gabungan (Sedlak, 1991). Pengolahan cara kimia dilakukan dengan menambahkan ke dalam air senyawa kimia yang dapat menurunkan kadar Fe dan Mn. Senyawa kimia yang umumnya digunakan yaitu kaporit (Darmasetiawan, 2004). Kaporit $\left(\mathrm{Ca}(\mathrm{OCl})_{2}\right)$ biasanya digunakan sebagai disinfektan karena efektif dan ekonomis, stabil dan daya simpan cukup lama (Surbakti, 1987). Tetapi efektivitas desinfektan bisa menurun dikarenakan adanya kandungan besi, mangan, amonia, sulfida (USEPA, 2002), dan padatan tarsuspensi (Tsai, 1999). Penelitian Azzahrah dan Susilawaty tahun 2014 mampu membuat kadar Fe turun sebesar $50,16 \%$ pada air sumur gali dengan menambahkan kaporit dengan dosis 2,5 mg/L. Menurut Aziz, et.al (2013) Penggunaan kaporit juga dapat menurunkan nilai TDS, TSS, BOD, COD, amonia, sulfida, fosfat, dan nitrit. Berdasarkan latar belakang diatas, maka diperlukan treatment salah satunya dengan penambahan kaporit guna menurunkan kandungan $\mathrm{Fe}$ dan $\mathrm{Mn}$ di dalam air sungai Ciliwung sebagai air baku sehingga kualitasnya memenuhi baku mutu yang dipersyaratkan.

\section{BAHAN DAN METODE}

\section{Bahan dan Alat}

Bahan - bahan yang digunakan dalam analisis ini adalah bahan uji dan bahan kimia. Bahan uji meliputi air sungai Ciliwung dari IPA Legong dan IPA Citayam. Bahan kimia yang digunakan meliputi Kaporit (Tjiwi Kimia), FerroZine Iron Reagent (HACH), Ascorbic Acid Powder (HACH), Alkaline Cyanide Reagent Solution (HACH), PAN Indicator Solution 0,1\% (HACH), aquadest, buffer $\mathrm{pH} 4(\mathrm{HACH})$ dan buffer $\mathrm{pH} 7$ (HACH).

Alat yang digunakan dalam pengujian adalah Spektrofotometer DR 3900, Turbidimeter merek HACH tipe 2100Q, pH meter merek WTW tipe 3114, TDS meter digital, Jartest, neraca analitik dan seperangkat alat gelas laboratorium.

\section{Metode}

Penelitian ini merupakan penelitian berbasis eksperimen. Populasi dalam penelitian ini yaitu air baku (air Sungai Ciliwung) yang berada dalam aliran IPA Legong dan IPA Citayam. Sampel air baku yang telah disampling dibubuhkan kaporit dengan pemberian 10 dosis yang berbeda.

Metode analisis yang dijadikan acuan untuk menentukan kadar besi berdasarkan FerroZine Rapid Liquid Method tahun 1970 (Akram, et al., 2020) dan mangan yaitu berdasarkan 1-(2Pyridylazo)-2-Napthol PAN Method tahun 1977 
(Goto, et al., 1977) dengan menggunakan metode Spektrofotometri.

\section{Sampling Air Baku}

Sampel uji yang digunakan adalah air baku yang bersumber dari air Sungai Ciliwung dari dua titik lokasi berbeda yaitu IPA Legong dan IPA Citayam dengan jarak $\pm 5 \mathrm{~km}$. Pengambilan sampel air dilakukan berdasarkan SNI 6898.58:2008. Air baku diambil dengan menggunakan pompa air submersible (pompa celup) yang berada di dasar sungai Ciliwung, lalu dialirkan ke dalam intake (bangunan untuk mengambil air baku dari sumber menuju instalasi pengolahan) menuju flashmix (bangunan untuk menampung air baku) menggunakan pipa. Air yang keluar dari pipa langsung diambil menggunakan jerigen. Jerigen yang digunakan memiliki kapasitas kurang lebih sebesar $20 \mathrm{~L}$.

Sampling dilakukan di dua titik lokasi berbeda. Proses sampling pada lokasi 1 (IPA Legong) dilakukan pada pukul 09.00 WIB dan lokasi 2 (IPA Citayam) dilakukan pada pukul 09.20 WIB.

\section{Persiapan Sampel}

Sampel uji di dalam jerigen dituang ke dalam ember dan homogenkan. Sampel $1000 \mathrm{~mL}$ dimasukkan masing-masing ke dalam piala gelas sebanyak 10 buah dan dihomogenkan.

Tabel 1. Dosis dan Bobot Kaporit dalam $1000 \mathrm{ml}$ sampel air sungai

\begin{tabular}{cc}
\hline Dosis Kaporit $(\mathrm{mg} / \mathrm{L})$ & Bobot Kaporit $(\mathrm{mg})$ \\
\hline 10 & 10 \\
20 & 20 \\
30 & 30 \\
40 & 40 \\
50 & 50 \\
60 & 60 \\
70 & 70 \\
80 & 80 \\
90 & 90 \\
100 & 100 \\
\hline
\end{tabular}

\section{Penambahan Dosis Kaporit}

Dosis kaporit yang digunakan adalah 10 dosis yang berbeda. Kaporit tersebut lalu ditambahkan ke dalam masing-masing sampel dan dihomogenkan selama 10 menit. Untuk mencegah menguapnya kaporit menjadi gas $\mathrm{Cl}_{2}$, sampel langsung dianalisis kadar besi dan mangannya.

\section{Pengukuran Kekeruhan}

Sampel air baku sebelum dan setelah perlakuan diukur masing-masing kekeruhannya menggunakan alat turbidimeter 2100Q. Turbidimeter dinyalakan kemudian sampel dimasukkan ke cuvet hingga tanda batas berwarna putih lalu dimasukkan ke dalam turbidimeter. Tekan tombol "read" tunggu hingga nilai akhir muncul pada monitor.

\section{Pengukuran Total Dissolved Solid (TDS)}

Sampel air baku sebelum dan setelah perlakuan diukur TDSnya dengan menggunakan TDS meter. Sampel diambil menggunakan gelas piala $100 \mathrm{ml}$ lalu TDS meter di-ON-kan dan dicelupkan ke dalam sampel 2-3 cm. Ditunggu beberapa saat, setelah angkanya stabil, dibaca nilai akhir. Tombol "hold" dapat ditekan untuk menghentikan pembacaan pengukuran, sehingga angka pengukuran tetap terbaca setelah TDS meter diangkat.

\section{Pengukuran pH}

Pengukuran $\mathrm{pH}$ terdiri dari kalibrasi dan pengukuran sampel. Untuk kalibrasi $\mathrm{pH}$ meter dinyalakan dengan tombol power berwarna merah, ditekan tombol CAL pilih ctl (AutoCal TEC) lalu tekan enter, selanjutnya elektroda dicelupkan ke dalam buffer $\mathrm{pH} 7$ dan akan mucul simbol AR flashing lalu ditunggu hasilnya hingga stabil dan symbol ct 2 menghilang. Elektroda dibilas lalu masukkan ke dalam larutan buffer $\mathrm{pH} 4$ dan akan mucul simbol AR flashing lalu ditunggu hasilnya hingga stabil dan symbol ct3 menghilang. Alat $\mathrm{pH}$ meter sudah siap digunakan. Untuk pengukuran sampel, pH meter dinyalakan dengan menekan tombol power berwarna merah. Elektroda dibilas lalu dimasukkan ke dalam sampel yang akan diuji. Sampel uji yang telah disampling, pHnya diukur sebelum dan sesudah penambahan kaporit dengan berbagai dosis.

\section{Pengujian Kadar Besi dan Mangan \\ Kalibrasi Spektrofotometer}

Spektrofotometer yang digunakan secara otomatis terkalibrasi saat dinyalakan sehingga saat analisis tidak perlu melakukan proses kalibrasi. 


\section{Pengujian Kadar Besi}

Sampel air baku diukur kadar besinya sebelum dan setelah treatment. Sampel air baku diambil masing-masing $50 \mathrm{~mL}$, dimasukkan ke dalam Erlenmeyer sebagai blanko dan sampel, dan ditambahkan $1 \mathrm{~mL}$ FerroZine Iron Reagent. Sampel dan blanko diukur dengan spektrofotometer pada program P261 dengan panjang gelombang $562 \mathrm{~nm}$.

\section{Pengujian Kadar Mangan}

Sampel air baku diukur kadar mangannya sebelum dan setelah treatment. Sampel air baku diambil $10 \mathrm{~mL}$ dan $10 \mathrm{~mL}$ aquadest dimasukkan ke dalam Erlenmeyer sebagai blanko, ditambahkan Ascorbic Acid Powder, 12 tetes Alkaline Cyanide Reagent Solution, dan 12 tetes PAN Indicator Solution 0,1\%. Sampel dan blanko diukur dengan spektrofotometer pada program P290 dengan panjang gelombang $560 \mathrm{~nm}$.

\section{Analisis Data}

Hasil kadar Fe dan Mn yang diperoleh dengan menggunakan Spektrofotometer dalam satuan $\mathrm{mg} / \mathrm{L}$ sehingga data dapat langsung diolah dengan cara menghitung persentase (\%) penurunan kadar $\mathrm{Fe}$ dan Mn dalam air sungai yang menggunakan berbagai dosis kaporit. Perhitugan \% penurunan kadar Fe dan Mn sebagai berikut:

$$
\%=\frac{\text { Kadar zat pretreatment }- \text { Kadar zat posttreatment }}{\text { Kadar zat pretreatment }} \times 100 \%
$$

Dosis kaporit dengan \% penurunan diatas $80 \%$ dikatakan efektif dan dapat digunakan sebagai acuan dosis guna menurunkan besi dan mangan yang terkandung di dalam air sungai Ciliwung.

\section{HASIL DAN PEMBAHASAN}

\section{Gambaran Umum Air Sungai Ciliwung}

Pada penelitian ini, air yang digunakan sebagai sampel adalah air Ciliwung yang dijadikan sebagai sumber air baku PDAM Depok. Data Pengendalian Pencemaran Air yang diperoleh dari Kementerian Lingkungan Hidup dan Kehutanan (KLHK) menunjukkan Sungai Ciliwung yang berada di Depok masih masuk dalam status tercemar kategori sedang dan dalam kurun waktu tiga tahun terakhir, pencemaran sungai Ciliwung yang berada di Kota Depok tidak mengalami perubahan status.
Tabel 2. Pengukuran Kekeruhan, TDS, pH, Besi dan Mangan Sungai Ciliwung

\begin{tabular}{lccc}
\hline \multicolumn{1}{c}{$\begin{array}{c}\text { Parameter } \\
\text { Pengujian }\end{array}$} & $\begin{array}{c}\text { IPA } \\
\text { Legong }\end{array}$ & $\begin{array}{c}\text { IPA } \\
\text { Citayam }\end{array}$ & PP No.82 \\
\hline Kekeruhan (NTU) & 111,0 & 33,7 & - \\
TDS (mg/L) & 340,0 & 178,0 & - \\
pH & 8,03 & 7,23 & $6,5-9,0$ \\
Besi (mg/L) & 0,593 & 0,436 & 0,3 \\
Mangan (mg/L) & 0,375 & 0,248 & 0,1 \\
\hline
\end{tabular}

Kualitas air Sungai Ciliwung di kedua lokasi secara fisik berwarna coklat dan berbau, hasil tersebut jika di dalam Peraturan Pemerintah No.82 Tahun 2001 tidak ada standarnya sehingga tidak dapat dibandingkan, sedangkan kadar besi dan mangan cukup tinggi higga melebihi standar Peraturan Pemerintah (PP) No.82 Tahun 2001 dengan Nilai Ambang Batas (NAB) untuk besi adalah $0,3 \mathrm{mg} / \mathrm{L}$ dan untuk mangan maksimal 0,1 $\mathrm{mg} / \mathrm{L}$. Surat Keputusan Menteri Lingkungan Hidup dan Kehutanan nomor 298/ MenLHK/ SetJen/ PKK.1/ 6/ 2017 tentang Penetapan Daya Tampung Beban Pencemaran Air dan Alokasi Beban Air Ciliwung menyebutkan bahwa pencemar yang dominan pada Daerah Aliran Sungai Ciliwung di Depok adalah limbah industri. Oleh sebab itu, cemaran logam besi dan mangan pada sampel cukup tinggi dan melebihi standar.

\section{Kekeruhan}

Kekeruhan air merupakan salah satu faktor yang mempengaruhi sediaan air karena selain mengurangi efektivitas usaha desinfeksi, dapat pula mengurangi segi estetika dan terhadap kekeruhan (Sutrisno, 2006).

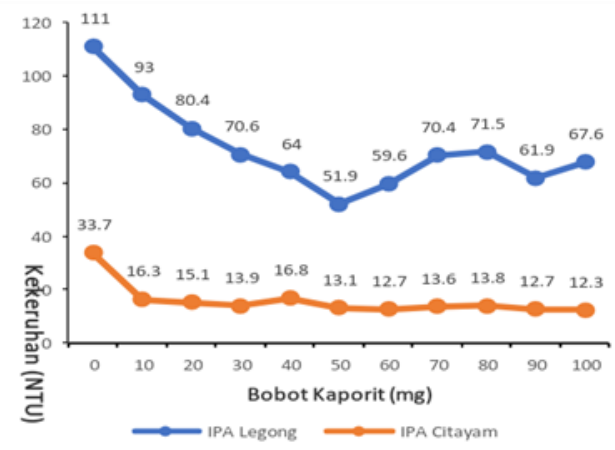

Gambar 1. Pengaruh Dosis Kaporit

Kekeruhan pada kedua sampel mengalami penurunan setelah ditambahkan kaporit dengan 
dosis yang berbeda, tetapi juga pada dosis tertentu kekeruhan pada kedua sampel mengalami kenaikan kembali yang disebabkan oleh penambahan kaporit berlebih. Kekeruhan pada air baku tidak mempunyai batas standar yang digunakan yaitu Peraturan Pemerintah No.82 Tahun 2001 sehingga hasil kekeruhan pada penelitian ini masih dikatakan layak dan dapat digunakan sebagai air baku di PDAM karena kekeruhan pada air tersebut dapat diturunkan melalui proses pengolahan air. Kaporit atau $\mathrm{Ca}(\mathrm{OCl})_{2}$ di dalam air akan berpisah menjadi ion kalsium $\left(\mathrm{Ca}^{2+}\right)$ dan hipoklorit $\left(\mathrm{ClO}^{-}\right)$. Ion $\mathrm{ClO}^{-}$ yang terbentuk bersifat reaktif yang dapat bereaksi dengan substansi-substansi lain yang terdapat di air seperti ion-ion sulfida, senyawa organik, amonia, dan bakteri yang menyebabkan tingkat kekeruhan dalam air menurun (Komala dan Yanarosanti, 2014).

\section{Total Padatan Terlarut/Total Dissolved Solid (TDS)}

Total Padatan Terlarut/Total Dissolved Solid (TDS) merupakan terlarutnya zat padat, berupa ion, senyawa dan koloid di dalam air. TDS umumnya terdiri dari zat organik, garam anorganik dan gas terlarut

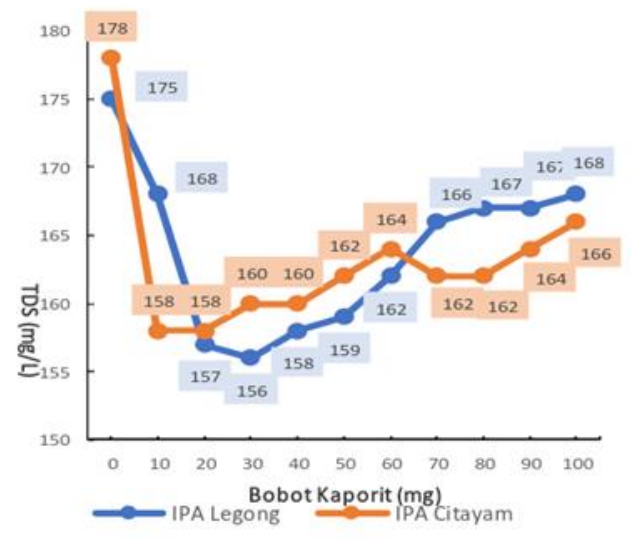

Gambar 2. Pengaruh Dosis Penggunaan Kaporit Terhadap Nilai TDS

Dapat terlihat pada Gambar 2, penambahan dosis kaporit dapat menurunkan kadar TDS di kedua sampel. Dosis kaporit yang paling terlihat dalam menurunkan kadar TDS yaitu dosis $20 \mathrm{mg} / \mathrm{L}$ dengan kadar TDSnya turun hingga $158 \mathrm{mg} / \mathrm{L}$ pada IPA Legong dengan persentase penurunan 9,7\% dan dosis $30 \mathrm{mg} / \mathrm{L}$ dengan kadar TDSnya turun hingga $156 \mathrm{mg} / \mathrm{L}$ pada IPA Citayam dengan persentase penurunan $12,4 \%$. Hal ini dikarenakan kaporit $\mathrm{Ca}(\mathrm{OCl})_{2}$ memiliki sifat oksidator yang akan mengoksidasi $\mathrm{Fe}^{2+}$ dan $\mathrm{Mn}^{2+}$ yang terlarut dalam air menjadi Fe dan Mn yang bervalensi lebih tinggi dan tidak dapat larut dalam air, yang kemudian diendapkan. Dapat dilihat dengan semakin banyak teroksidasinya Fe dan Mn terlarut maka nilai TDS akan semakin menurun, walaupun terjadi kenaikan kadar TDS kembali setelah mengalami penurunan karena penambahan kaporit yang berlebih, tetapi hasil kadar TDS dari kedua sampel masih memenuhi standar PP No.82 kelas 1 yaitu maksimum $1000 \mathrm{mg} / \mathrm{L}$.

\section{Derajat Keasaman (pH)}

$\mathrm{pH}$ pada penelitian ini mengalami perbedaan dari masing-masing perlakuan. Pada penggunaan 10 variasi dosis kaporit yang digunakan, diperoleh hasil pH air Sungai Ciliwung sebesar 8,03 - 8,41 pada sampel IPA Legong, 7,23 - 8,19 pada sampel IPA Citayam, sehingga hasil pada kedua sampel sudah sesuai dengan standar yang ditetapkan dalam PP No.82 Tahun 2001 dengan pH 6,5 - 9,0. $\mathrm{pH}$ yang berubah mengarah pada $\mathrm{pH}$ basa disebabkan oleh kaporit. Semakin banyak kaporit yang ditambahkan maka $\mathrm{pH}$ air akan semakin meningkat (Sawyer, 2003). Reaksi yang terjadi yaitu:

$2 \mathrm{Ca}(\mathrm{OCl})_{2(\mathrm{~s})}+2 \mathrm{H}_{2} \mathrm{O}_{(\mathrm{l})} \rightarrow \underset{ }{2 \mathrm{HCl}_{(\mathrm{aq})}+\mathrm{O}_{2(\mathrm{~g})} \uparrow}+2 \mathrm{HOCl}_{(\mathrm{aq})}+$

$\mathrm{Ca}(\mathrm{OH})_{2(\mathrm{~s})} \rightarrow \mathrm{Ca}^{2+}{ }_{(\mathrm{aq})}+\mathrm{OH}^{-}{ }_{(\mathrm{aq})}$

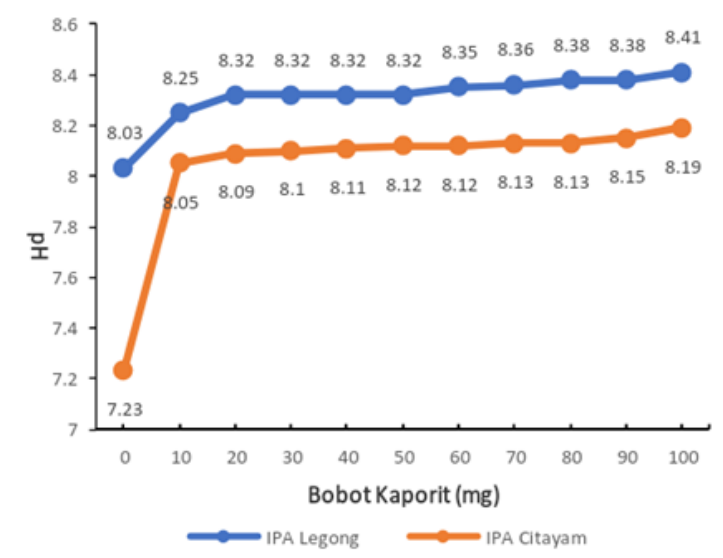

Gambar 3. Pengaruh Dosis Kaporit Terhadap $\mathrm{pH}$ 
Kaporit $\left(\mathrm{Ca}(\mathrm{OCl})_{2}\right)$ di dalam air terhidrolisis menghasilkan basa kuat yaitu $\mathrm{Ca}(\mathrm{OH})_{2}$ dan asam lemah yaitu $\mathrm{HOCl}$. Basa kuat $\mathrm{Ca}(\mathrm{OH})_{2}$ akan terurai membentuk $\mathrm{Ca}^{2+}$ dan $\mathrm{OH}^{-}$menghasilkan perbandingan $\mathrm{OH}^{-}$lebih tinggi daripada ion $\mathrm{H}^{+}$ yang mengakibatkan $\mathrm{pH}$ air cenderung basa (Sawyer, 2003).

\section{Kadar Besi}

Umumnya air sungai mengandung besi disebabkan oleh air mengalami kontak langsung dengan lapisan tanah yang mengandung $\mathrm{Fe}$ di dalamnya. Fe merupakan logam essensial yang dalam kadar tertentu sangat diperlukan oleh organisme hidup, tetapi dalam jumlah berlebihan bisa menyebabkan efek toksik (Supriyantini dan Endrawati, 2015). Hasil pengujian kandungan besi dalam air sungai Ciliwung sebelum dan sesudah penambahan kaporit dengan 10 dosis berbeda ditunjukkan pada Gambar 4.

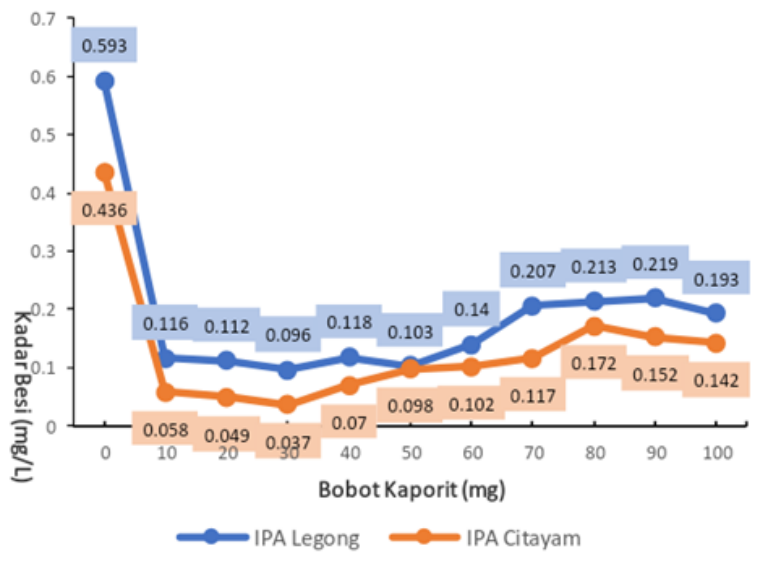

Gambar 4. Pengaruh Dosis Kaporit Terhadap Kadar Besi

Dari Gambar 4, dapat dilihat perbedaan penurunan dari pemberian kaporit pada dosis 10 mg/L hingga $30 \mathrm{mg} / \mathrm{L}$ pada kedua sampel. Hal ini menunjukkan bahwa penurunan kadar besi disebabkan oleh pemberian kaporit sedangkan pada dosis 40 hingga $100 \mathrm{mg} / \mathrm{L}$ pada kedua sampel, kadar besi mengalami kenaikan, tetapi tidak signifikan dan masih memenuhi baku mutu yang dipersyaratkan. Kenaikan ini terjadi kemungkinan karena pengadukan dengan jar test yang tidak homogen, menyebabkan $\mathrm{Fe}^{2+}$ masih terlarut dalam air dan terukur sebagai kadar besi dalam air. Kadar besi di kedua sampel setelah pemberian kaporit dengan 10 dosis berbeda, diperoleh hasil yang sudah memenuhi baku mutu yang ditetapkan pada PP No.82 Tahun 2001 yang menyatakan bahwa kadar besi pada pengolahan persediaan air maksimal $0,3 \mathrm{mg} / \mathrm{L}$.

Pada proses pengolahan air minum, senyawa besi bervalensi dua $\mathrm{Fe}^{2+}$ (ferro) yang dapat larut dalam air harus diubah menjadi senyawa besi bervalensi tiga $\mathrm{Fe}^{3+}$ (ferri) yang tidak dapat larut di dalam air, sehingga mudah diendapkan dan dipisahkan (Tatsumi, 1971). Menurut Giyantini (2004), kaporit yang ditambahkan ke dalam air akan mengoksidasi besi menjadi bentuk senyawa yang tidak dapat larut dalam air, sehingga mudah diendapkan dan dipisahkan. Oleh sebab itu kadar besi dalam air dapat menurun setelah penambahan kaporit. Reaksi yang terjadi antara klorin yang terdapat dalam kaporit dengan besi dalam air merupakan reaksi oksidasi dengan persamaan reaksi sebagai berikut:

$$
\begin{aligned}
& 2 \mathrm{Ca}(\mathrm{OCl})_{2(\mathrm{~s})}+2 \mathrm{H}_{2} \mathrm{O}_{(\mathrm{l})} \rightarrow \underset{\left(\mathrm{CaO}{ }_{(\mathrm{s})}+2 \mathrm{HOCl}_{(\mathrm{aq})}\right.}{2 \mathrm{HCl}_{(\mathrm{aq})}+\mathrm{O}_{2(\mathrm{~g})} \uparrow}+ \\
& 2 \mathrm{HCl}_{(\mathrm{aq})} \rightarrow \mathrm{H}_{2(\mathrm{~g})}+\mathrm{Cl}_{2(\mathrm{~g})} \\
& 2 \mathrm{Fe}^{2+}{ }_{(\mathrm{aq})}+\mathrm{Cl}_{2(\mathrm{~g})}+6 \mathrm{H}_{2} \mathrm{O}_{(\mathrm{l})} \rightarrow \underset{(\mathrm{aq})}{2 \mathrm{Fe}(\mathrm{OH})_{3(\mathrm{~s})}+6 \mathrm{H}^{+}{ }_{(\mathrm{aq})}}+2 \mathrm{Cl}^{-}
\end{aligned}
$$

\section{Kadar Mangan}

Keberadaan Mn di alamberupa unsur bebas dalam sifat dasarnya dan sering bercampur dengan $\mathrm{Fe}$, seperti mineral-mineral lainnya (Indra et al., 2020). Keberadaan logam Mn dan Fe dalam air berasal dari tanah dan batu-batuan. Bentuk Mn dalam air berupa senyawa mangan bikarbonat (Mn(HCO3)2), mangan sulfat (MnSO4), dan mangan klorida (MnCl2) (Said, 2005). Hasil pengukuran kadar Mn dalam air sungai Ciliwung, sebelum perlakuan dan sesudah penambahan kaporit menggunakan 10 dosis berbeda ditunjukkan pada Gambar 5. Terdapat perbedaan penurunan dari pemberian kaporit. Sampel IPA Legong mengalami penurunan pada dosis $10 \mathrm{mg} / \mathrm{L}$ hingga $70 \mathrm{mg} / \mathrm{L}$, sedangkan sampel IPA Citayam mengalami penurunan pada dosis $10 \mathrm{mg} / \mathrm{L}$ hingga $60 \mathrm{mg} / \mathrm{L}$. Hal ini menunjukkan bahwa penurunan kadar mangan disebabkan oleh pemberian kaporit, sedangkan pada dosis 80 hingga $100 \mathrm{mg} / \mathrm{L}$ pada sampel IPA Legong dan dosis 70 hingga $100 \mathrm{mg} / \mathrm{L}$ pada IPA Citayam mengalami kenaikan kembali kadarnya karena pemberian kaporit yang berlebih. 


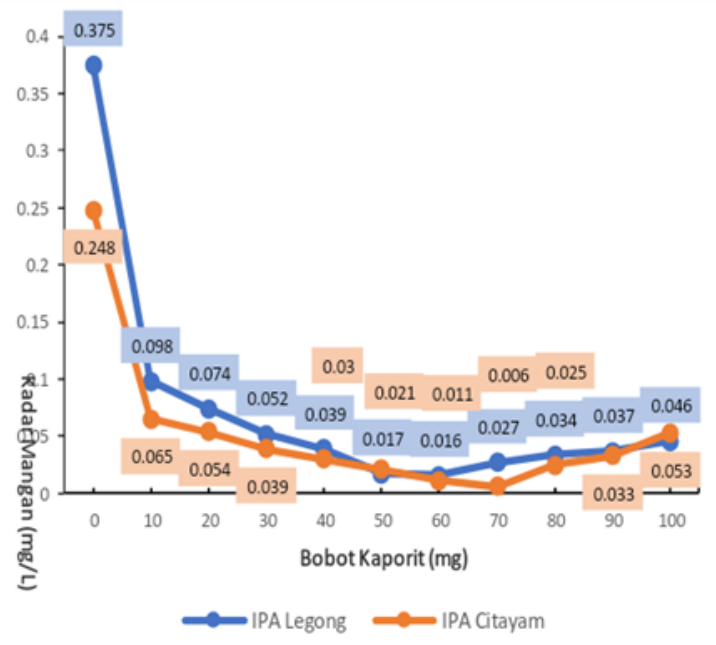

Gambar 5. Pengaruh Dosis Kaporit Terhadap Kadar Mangan

Senyawa Mn pada umumnya mempunyai valensi yang bermacam-macam. Kadar Mn dan Fe dapat berubah bergantung pada $\mathrm{pH}$ air. Klorin atau lebih dikenal dengan kaporit merupakan oksidator kuat, meskipun air dalam keadaan derajat keasamannya rendah dan oksigen terlarut dalam jumlah sedikit, tetapi klorin mampu mengoksidasi Fe dan Mn dengan cepat. Reaksi oksidasi antara $\mathrm{Mn}$ dengan $\mathrm{Cl}$ ditunjukkan dengan persamaan reaksi di bawah ini:

$$
\begin{aligned}
2 \mathrm{Ca}(\mathrm{OCl})_{2(\mathrm{~s})}+2 \mathrm{H}_{2} \mathrm{O}(\mathrm{l}) \rightarrow & 2 \mathrm{CaO}(\mathrm{s}) \\
& 2 \mathrm{HCl}_{(\mathrm{aq})}+\mathrm{O}_{2(\mathrm{~g})} \uparrow
\end{aligned}
$$$$
2 \mathrm{HCl}_{(\mathrm{aq})} \rightarrow \mathrm{H}_{2(\mathrm{~g})}+\mathrm{Cl}_{2(\mathrm{~g})}
$$$$
\mathrm{Mn}^{2+}{ }_{(\mathrm{aq})}+\mathrm{Cl}_{2(\mathrm{aq})}+2 \mathrm{H}_{2} \mathrm{O}{ }_{(\mathrm{l})} \rightarrow \mathrm{MnO}_{2(\mathrm{~s})}+2 \mathrm{Cl}^{-}{ }_{(\mathrm{aq})}
$$$$
+4 \mathrm{H}^{+} \text {(aq) }
$$

Dalam sistem pengolahan air, senyawa Mn yang bervalensi lebih tinggi tidak dapat larut air sehingga mudah dipisahkan secara fisik (Eaton et $a l ., 2005)$. Penambahan dosis kaporit yang berlebih akan menyebabkan kadar mangan meningkat bersamaan dengan meningkatnya $\mathrm{pH}$ sehingga membentuk persenyawaan mangan yang tidak dapat larut dalam air berupa $\mathrm{MnO}_{2}, \mathrm{MnCO}_{3}$, dan $\mathrm{Mn}_{3} \mathrm{O}_{4}$ (Achmad, 2004).

\section{Efektivitas Dosis Kaporit}

Kaporit dikatakan efektif jika efisiensi penurunan kadar Fe dan Mn mencapai 80\% menurut tingkat efektivitas (Indra et.al, 2020). Kaporit dibubuhkan ke air baku dari rentang 10 $\mathrm{mg}-100 \mathrm{mg}$ dalam $1000 \mathrm{~mL}$ sampel. Masingmasing dosis kaporit yang diberikan mendapatkan hasil kadar besi dan mangan yang berbeda, sehingga dapat dihitung persentase penurunan kadarnya untuk melihat efektivitas kaporit pada penurunan kadar Fe dan Mn.

Tabel 3. Persentase Penurunan Kadar Besi Sesudah Pemberian Kaporit dengan

\begin{tabular}{|c|c|c|}
\hline \multirow[t]{2}{*}{$\begin{array}{l}\text { Bobot } \\
\text { Kaporit } \\
(\mathrm{mg})\end{array}$} & \multicolumn{2}{|c|}{$\begin{array}{c}\text { Persentase penurunan kadar } \\
\text { besi } \\
(\%)\end{array}$} \\
\hline & IPA Legong & IPA Citayam \\
\hline 10 & 80,44 & 86,70 \\
\hline 20 & 81,11 & 88,76 \\
\hline 30 & 83,81 & 91,51 \\
\hline 40 & 80,10 & 83,94 \\
\hline 50 & 82,63 & 77,52 \\
\hline 60 & 76,39 & 76,61 \\
\hline 70 & 65,09 & 73,17 \\
\hline 80 & 64,08 & 60,55 \\
\hline 90 & 63,07 & 65,14 \\
\hline 100 & 67,45 & 67,43 \\
\hline
\end{tabular}
Berbagai Variasi Dosis.

Kaporit dengan dosis $10 \mathrm{mg} / \mathrm{L}$ hingga 50 $\mathrm{mg} / \mathrm{L}$ pada sampel IPA Legong dan $10 \mathrm{mg} / \mathrm{L}$ hingga $40 \mathrm{mg} / \mathrm{L}$ pada sampel IPA Citayam dikatakan sudah efektif karena berhasil menurunkan kandungan besi lebih dari $80 \%$. Kaporit dengan dosis $60 \mathrm{mg} / \mathrm{L}$ hingga $100 \mathrm{mg} / \mathrm{L}$ pada sampel IPA Legong dan $50 \mathrm{mg} / \mathrm{L}$ hingga 100 $\mathrm{mg} / \mathrm{L}$ pada sampel IPA Citayam kurang efektif dikarenakan penambahan kaporit yang berlebih menyebabkan kadar besi mengalami kenaikan kembali.

Kaporit dengan dosis $10 \mathrm{mg} / \mathrm{L}$ pada sampel IPA Legong dan $10 \mathrm{mg} / \mathrm{L}, 20 \mathrm{mg} / \mathrm{L}$ dan $100 \mathrm{mg} / \mathrm{L}$ pada sampel IPA Citayam kurang efektif sedangkan kaporit dengan dosis $20 \mathrm{mg} / \mathrm{L}$ hingga $100 \mathrm{mg} / \mathrm{L}$ pada sampel IPA Legong dan $30 \mathrm{mg} / \mathrm{L}$ hingga $90 \mathrm{mg} / \mathrm{L}$ pada sampel IPA Citayam sudah efektif karena mampu menurunkan kadar mangan hingga lebih dari $80 \%$. Hasil kadar mangan pada kedua sampel setelah penambahan kaporit sudah memenuhi nilai baku mutu sehingga sesuai dengan baku mutu yang telah ditetapkan dalam PP No.82 Tahun 2001 yang menyatakan bahwa kadar Mn pada pengelolaan kualitas air maksimal $0,1 \mathrm{mg} / \mathrm{L}$. 
Tabel 4. Persentase Penurunan Kadar Mangan Sesudah Penambahan Kaporit dengan Berbagai Variasi Dosis.

\begin{tabular}{|c|c|c|}
\hline \multirow{2}{*}{$\begin{array}{l}\text { Bobot } \\
\text { Kaporit } \\
(\mathrm{mg})\end{array}$} & \multicolumn{2}{|c|}{$\begin{array}{c}\text { Persentase penurunan kadar } \\
\text { mangan } \\
(\%) \\
\end{array}$} \\
\hline & IPA Legong & IPA Citayam \\
\hline 10 & 73,87 & 73,79 \\
\hline 20 & 80,27 & 78,23 \\
\hline 30 & 86,13 & 84,27 \\
\hline 40 & 89,60 & 87,90 \\
\hline 50 & 95,47 & 91,53 \\
\hline 60 & 95,73 & 95,56 \\
\hline 70 & 92,80 & 97,58 \\
\hline 80 & 90,93 & 89,92 \\
\hline 90 & 90,13 & 86,69 \\
\hline 100 & 87,73 & 78,63 \\
\hline
\end{tabular}

Besarnya penurunan kadar besi dan mangan seiring dengan semakin banyak dosis kaporit yang diberikan, tetapi bila penambahan dosis kaporit berlebih akan menyebabkan kadar besi dan mangan akan mengalami kenaikan kembali. Semakin besar dosis kaporit sampai batas tertentu, maka semakin besar pula kadar besi, mangan dan kekeruhan yang turun tetapi $\mathrm{pH}$ dan TDS akan semakin meningkat. Dari data yang diperoleh, dosis optimum untuk penurunan Fe yaitu $10 \mathrm{mg} / \mathrm{L}$ sedangkan dosis optimum penurunan Mn yaitu 30 $\mathrm{mg} / \mathrm{L}$. Dosis tersebut efektif menurunkan kadar Fe dan Mn dalam sampel air sungai Ciliwung yang digunakan sebagai air baku IPA Legong dan Citayam sebesar $80 \%$.

\section{KESIMPULAN}

Berdasarkan hasil penelitian, dapat disimpulkan bahwa air sungai Ciliwung yang digunakan sebagai air baku di PDAM mengalami cemaran logam Fe dengan nilai kandungan 0,436$0,593 \mathrm{mg} / \mathrm{L}$ dan $\mathrm{Mn}$ dengan nilai kandungan 0,248-0,375 mg/L jika dibandingkan dengan baku mutu yang ditetapkan oleh PP RI No. 82 tahun 2001 tentang pengolahan kualitas air dan pengendalian pencemaran air.

Penambahan kaporit ke dalam air sungai Ciliwung pada IPA Legong dan Citayam sudah efektif dalam menurunkan kandungan $\mathrm{Fe}$ dan $\mathrm{Mn}$ karena mampu menurunkan kadarnya hingga 80\% dari konsentrasi awal. Dosis kaporit yang paling efektif untuk air sungai Ciliwung di IPA Legong dan Citayam adalah $10 \mathrm{mg} / \mathrm{L}$ untuk penurunan kadar Fe dan 30 mg/L untuk penurunan kadar Mn.

Semakin banyak dosis kaporit yang diberikan sampai batas tertentu, maka semakin besar pula penurunan kadar $\mathrm{Fe}, \mathrm{Mn}$ dan kekeruhan. Sebaliknya untuk pH dan TDS akan meningkat.

\section{DAFTAR PUSTAKA}

Achmad, R. (2004). Kimia Lingkungan. Edisi 1. Andi Offset. Yogyakarta.

Akram, M., Asghar, M. N., Khan, M. S., Shahid, S., Rahman, H. M. A., \& Nadeem, I. (2020). Development and validation of an economical uric acid- $\mathrm{Fe}^{3+} / \mathrm{Fe}^{2+}$-ferrozinebased colorimetric assay to estimate uric acid level of pure and biological samples.

Bioscience, Biotechnology, and Biochemistry. https://doi.org/10.1080/09168451.2020.1 781593

Aziz, T., Pratiwi, D.Y. \& Rethiana, L. (2013). Pengaruh Penambahan Tawas $\mathrm{Al}_{2}\left(\mathrm{SO}_{4}\right)_{3}$ dan Kaporit $\mathrm{Ca}(\mathrm{OCl})_{2}$ Terhadap Karakter Fisik dan Kimia Air Sungai Lambidaro. Jurnal Teknik Kimia, 19(3).

Azzahra, F., \& Susilawaty, A. (2014). Efektivitas Pembubuhan Kaporit dalam Menurunkan Kadar Zat Besi (Fe) pada Air Sumur Gali Tahun 2013. Journal Kesehatan, VII (1).

Darmasetiawan, M. (2004). Teori dan Perencanaan Instalasi Pengolahan Air. Ekamitra Engineering. Jakarta.

Eaton, A.A., Clescerl, L.S., Rice, E.W., \& Greenberg, A.E. (2005). Standard Methods for The Examination of Water and Wastewater, 21st Edition. American Public Health Association (APHA), Washington, D.C; American Water Works Association (AWWA), Denver, Colorado; and Water Environment Federation (WEF), Alexandria, Virginia. 
Effendi, H. (2003). Telaah Kualitas Air. Kanasius. Yogyakarta

Ginting, P. (2007). Sistem Pengelolaan Lingkungan dan Limbah Indsutri. Yrama Widya. Bandung.

Giyantini. (2004). Deinfeksi Air dengan Chlorinasi. Journal Info Penyehatan Air dan Sanitasi, VI(2).

Goto, K., Taguchi, S., Fukue, Y., Ohta, K. (1977). Spectrophotometric Determination of Manganese with 1-(2-pyridylazo)-2naphthol and a non-ionic surfactant. Talanta, 24, 752-753.

Indra. A., Armid, \& Takwir, A. (2020). Distribusi Logam Berat Mangan (Mn) Pada Air Laut Permukaan Di Perairan Teluk Staring Sulawesi Tenggara. Jurnal Kelautan, 5(1):89-98.

Komala, P. S. \& Yanarosanti, A. (2014). Inaktivasi Bakteri Escherichia coli Air Sumur Menggunakan Disinfektan Kaporit. Jurnal Teknik Lingkungan UNAND, 11(1), 34-47.

Peraturan Pemerintah. (2001). Peraturan Pemerintah Republik Indonesia Nomor 82 Tahun 2001 Tentang Pengelolaan Kualitas Air dan Pengendalian Pencemaran Air.

Said, N.I. (1999). Teknologi Pengolahan Air. Direktorat Teknologi Lingkungan dan Kelompok Teknologi Pengelolaan Air Bersih dan Limbah Cair. Jakarta.

Said, N.I. (2005). Metoda Penghilangan Zat Besi Dan Mangan Di Dalam Penyediaan Air Minum Domestik. Jurnal Air Indonesia, l(3).

Sawyer, C.N., McCarty, P.L., Parkin, G.F. (2003). Chemistry for Enviromental Engineering and Science. McGrawHill. New York.

Sedlak, R. (1991). Phosphorus and Nitrogen Removal from Municipal Wastewater: Principles and Practice (2nd ed.). Boca Raton. Lewis.

Simon, S.B. \& Hidayat, R. (2008). Pengendalian Pencemaran Sumber Air Dengan Ekoteknologi (Wetland Buatan). Jurnal Sumber Daya Air, 4, 111-124.
Sofia, Y., Tontowi, \& Rahayu, S. (2010).

Penelitian Pengolahan Air Sungai Yang Tercemar Oleh Bahan Organik. Jurnal Sumber Daya Air, 6, 145-160.

Supriyantini, E., \& Endrawati, H. (2015). Kandungan Logam Berat Besi (Fe) Pada Air. Sedimen. dan Kerang Hijau (Perna viridis) di Perairan Tanjung Emas Semarang. Jurnal Kelautan Tropis, 6(18).

Slamet, S.J. (1994). Kesehatan Lingkungan. Gadjah Mada University Press. Bandung.

Surbakti, B.M. (1987). Air Minum Sehat. CV Mutiara Solo. Surakarta

Sutrisno, T.C. (2010). Teknologi Penyediaan Air Bersih. Rineka Cipta. Jakarta.

Tarigan, M.S., \& Edward. (2003). Kandungan Total Zat Padat Tersuspensi (Total Suspended Solid) di Perairan Raha Sulawesi Tenggara. Jurnal Bidang Dinamika Laut, Pusat Penelitian Oseanografi, Makara Sains, 7 (3), 109. 119.

Tatsumi, I. (1971). Water Work Engineering (JOSUI KOGAKU). Japanese Edition. Tokyo.

Tsai, C.T., \& Lin, T.S. (1999). Disinfection of hospital waste sludge using hypochlorite and chlorine dioxide. Journal of Applied Microbiology, 86, 827-833.

USEPA. (2002). Onsite Wastewater Treatment Sistems Technology Fact Sheet 4: Effluent Disinfection Processes. TFS-17-TFS-22, EPA/625/R-00/008, February. 